\title{
Linking microbial communities, functional genes and nitrogen-cycling processes in forest floors under four tree species
}

Ribbons, Relena; Levy-Booth, David J.; Masse, Jacynthe; Grayston, Sue J.; McDonald, Morag; Vesterdal, Lars; Prescott, Cindy E.

\section{Soil Biology and Biochemistry}

DOI:

10.1016/j.soilbio.2016.07.024

Published: 01/12/2016

Peer reviewed version

Cyswllt i'r cyhoeddiad / Link to publication

Dyfyniad o'r fersiwn a gyhoeddwyd / Citation for published version (APA):

Ribbons, R., Levy-Booth, D. J., Masse, J., Grayston, S. J., McDonald, M., Vesterdal, L., \& Prescott, C. E. (2016). Linking microbial communities, functional genes and nitrogen-cycling processes in forest floors under four tree species. Soil Biology and Biochemistry, 103(December), 181-191. https://doi.org/10.1016/j.soilbio.2016.07.024

\section{Hawliau Cyffredinol / General rights}

Copyright and moral rights for the publications made accessible in the public portal are retained by the authors and/or other copyright owners and it is a condition of accessing publications that users recognise and abide by the legal requirements associated with these rights. study or research.

- Users may download and print one copy of any publication from the public portal for the purpose of private

- You may not further distribute the material or use it for any profit-making activity or commercial gain

- You may freely distribute the URL identifying the publication in the public portal ?

Take down policy

If you believe that this document breaches copyright please contact us providing details, and we will remove access to the work immediately and investigate your claim. 


\section{Linking microbial communities, functional genes and nitrogen-cycling processes in forest}

2 floors under four tree species

4 Authors: Relena R. Ribbons ${ }^{123^{*}}$, David J. Levy-Booth ${ }^{4}$, Jacynthe Masse ${ }^{1}$, Sue J. Grayston ${ }^{1}$, 5 Morag A. McDonald ${ }^{2}$, Lars Vesterdal ${ }^{3}$, and Cindy E. Prescott ${ }^{1}$

\section{Affiliations:}

$8{ }^{1}$ Department of Forest and Conservation Sciences, Faculty of Forestry, University of British

9 Columbia-Vancouver, Forest Sciences Centre 3006, 2424 Main Mall, Vancouver, British

10 Columbia, V6T 1 Z4 Canada; ${ }^{2}$ School of Environment, Natural Resources, and Geography,

11 Bangor University, Thoday Building, Bangor, LL57 2UW, Wales, United Kingdom;

$12{ }^{3}$ Department of Geosciences and Natural Resource Management, University of Copenhagen,

13 Rolighedsvej 23, DK-1958 Frederiksberg C, Denmark; ${ }^{4}$ Department of Microbiology and

14 Immunology, University of British Columbia, Vancouver, British Columbia V6T 1Z4, Canada

15

16 Author for correspondence:

17 Relena R. Ribbons

18 Tel: +4501248382450

19 Email: rribbons@gmail.com 


\section{Abstract}

Tree species can influence rates of soil $\mathrm{N}$ transformations, but the question remains whether differences in $\mathrm{N}$ cycling rates are mirrored by the abundance of relevant functional genes. We studied whether the influence of tree species on soil $\mathrm{N}$ transformation processes and abundance of functional genes exist across two sites in British Columbia with different $\mathrm{N}$ availability. We used the ${ }^{15} \mathrm{~N}$ pool-dilution method to estimate gross rates of ammonification and nitrification in forest floors of four conifers in a common garden experiment. The abundances of bacteria, fungi, nitrification (AOA amoA, AOB amoA) and denitrification (nirs, nirK) genes were determined by qPCR. Western red cedar (Thuja plicata) had the highest rates of gross ammonification and $\mathrm{NH}_{4}{ }^{+}$consumption, followed by Sitka spruce (Picea sitchensis), hemlock

44 (Tsuga heterophylla), and Douglas-fir (Pseudotsuga menziesii); all species showed net nitrate immobilization. Western red cedar forest floors had the greatest abundance of bacterial $16 \mathrm{~S}$ genes and ammonia-oxidizing archaea amoA genes. This suggests that tree species foster different abundances of ammonification and denitrification functional groups. Differences in $\mathrm{N}$ transformation rates between the sites were related to site $\mathrm{N}$ status, as reflected in $\mathrm{C}: \mathrm{N}$ ratios of the forest floor and microbial biomass, and were more closely tied to rates of $\mathrm{N}$ consumption rather than gross mineralization. Rates of most $\mathrm{N}$ transformation processes were related to microbial $\mathrm{C}: \mathrm{N}$ ratio, indicating that the $\mathrm{N}$ status of microbes rather than their biomass or activity level determined the rates of $\mathrm{N}$ cycling. Ammonification rates were associated with forest floor and microbial biomass $\mathrm{C}: \mathrm{N}$ ratio as well as bacterial and fungal abundances. Nitrification rates and denitrification gene abundance were associated with microbial biomass $\mathrm{C}: \mathrm{N}$ ratios and AOA amoA gene abundance. The forest floor's genetic potential for denitrification was positively correlated with its nitrification potential as indicated by ammonia-oxidizer abundance. We conclude that tree species influenced forest floor $\mathrm{N}$ cycling and soil microbial gene abundances, and that functional genetics can be useful for exploring mechanistic links between tree species and nitrogen cycling processes.

61 Keywords: Ammonia oxidizers, nitrifiers, ${ }^{15} \mathrm{~N}$ pool dilution, tree species effects, nitrogen

62 cycling, forest floors 


\section{Introduction}

Nitrogen $(\mathrm{N})$ availability is often the primary limitation on ecosystem productivity in conifer forests (Vitousek et al., 1997, 2002; LeBauer and Treseder, 2008), and factors that regulate $\mathrm{N}$ availability have far-reaching consequences for ecosystem properties such as microbial activity, biogeochemical cycling, carbon (C) sequestration, aboveground biomass production and greenhouse gas (GHG) fluxes. Soil N transformation processes (e.g., mineralization of organic $\mathrm{N}$ to $\mathrm{NH}_{4}{ }^{+}$and nitrification of $\mathrm{NH}_{4}{ }^{+}$to $\mathrm{NO}_{3}{ }^{-}$) are largely mediated by interactions between functional communities of soil microorganisms and their environment (Bengtsson et al., 2003; Balser and Firestone, 2005; Högberg et al., 2013). The balance between gross and net rates of mineralization and nitrification can indicate turnover and immobilization rates of $\mathrm{NH}_{4}{ }^{+}$and $\mathrm{NO}_{3}{ }^{-}$, respectively, which can be rapid in forest soil (Davidson et al., 1992;

75 Stark and Hart, 1997). Rates of mineralization and nitrification have further implications for $\mathrm{N}$ loss through leaching of $\mathrm{NO}_{3}{ }^{-}$and denitrification to $\mathrm{N}_{2} \mathrm{O}$ (Bengtsson et al., 2003; Szukics et al., 77 2010).

Quantification of marker genes for biogeochemical functions can be used to characterize $\mathrm{N}$ cycling processes and communities (Levy-Booth et al., 2014). Ammonia-oxidizing archaea (AOA) and bacteria (AOB) carry out the first, and potentially rate-limiting, step of nitrification. $\mathrm{AOA}$ and $\mathrm{AOB}$ abundance can be quantified using the ammonia-monooxygenase (amoA) gene (Rotthauwe et al., 1997; Francis et al., 2005; Leininger et al., 2006; Szukics et al., 2010). While AOB have long been thought to dominate ammonia-oxidation, the quantitative importance of AOA in soil has recently been recognized (Leininger et al., 2006; Petersen et al., 2012), and AOA are generally more abundant than AOB in acidic forest soil (Petersen et al., 2012). The relative contributions of $\mathrm{AOA}$ and $\mathrm{AOB}$ to gross and net nitrification in forests with different tree species remain to be seen. Denitrification is a biological pathway through which $\mathrm{N}$ returns to the atmosphere from soil or water by the reduction of nitrate to nitrous oxide (Henry et al., 2004) via the nitrite reductase enzyme genes nirS and nirK. Genes that encode enzymes involved in biogeochemical cycling can be used to compare measured $\mathrm{N}$ mineralization and nitrification rates with bacterial, fungal, nitrifier and denitrifier population sizes (inferred from gene abundances) and in so doing, link N-cycling pathways to functional microbial groups.

94 particularly forest floor layers, and rates of processes therein. Tree species influence soils 
95 directly via leaf litter inputs and formation of forest floors (Hobbie et al., 2006; Vesterdal et al., 96 2012), and via root litter inputs and alteration of soil structure. Tree species also influence rates

97 of litter decomposition, nutrient release, $\mathrm{C}$ turnover and soil respiration through differences in

98 foliar N, Ca, Mg and lignin concentrations (Hobbie et al., 2006; Vesterdal et al., 2012,

99 2013). Several studies have reported differences in rates of $\mathrm{N}$-cycling processes in soils under

100 different tree species (e.g., Ste-Marie and Paré, 1999; Malchair and Carnol, 2009; Christiansen et

101 al., 2010), and distinct microbial communities have also been reported in soils and forest floors

102 under different tree species (Leckie et al., 2005; Prescott and Grayston, 2014). However, despite

103 decades of research on this question, categorization of species according to their influence of soil

104 properties has proven elusive, as tree species effects have been inconsistent among studies, and

105 even at different sites within a single study. For example, in a common garden experiment on

106 Vancouver Island, the indirect influence of site factors (particularly slope position) on rates of

107 net $\mathrm{N}$ mineralization and nitrification in the forest floors appeared to overwhelm the influence of

108 tree species, with appreciable net rates detected only at the valley bottom sites where the forest

109 floor C:N ratio was less than 35 (Prescott et al., 2000a). Likewise, Gurmesa et al. (2013) found

110 an influence of broadleaved tree species on soil carbon only at relatively rich sites, which they

111 attributed to the lack of earthworms at the infertile sites, regardless of tree species. These

112 observations prompted Prescott and Vesterdal (2013) to propose that the expression of tree

113 species influence on soils is context-dependent, and more likely to be detectable on rich or

114 intermediate sites.

115 In the common garden experiment on Vancouver Island, previous studies of the forest

116 floors discerned some distinct characteristics of the forest floors under four coniferous tree

117 species, which have been summarized by Prescott and Vesterdal (2005). Western red cedar forest

118 floors had the lowest rates of litter decomposition and net $\mathrm{N}$ mineralization, but the highest

119 proportion of nitrate and the highest bacterial:fungal ratio of the four species. Western hemlock

120 forest floors had low $\mathrm{pH}$ and low Ca concentrations, low bacteria:fungal ratios, and were

121 dominated by $\mathrm{NH}_{4}{ }^{+}$rather than nitrate. Sitka spruce forest floors had intermediate to high

122 concentrations of $\mathrm{N}, \mathrm{P}, \mathrm{Ca}$, and $\mathrm{K}$, low bacterial:fungal ratios, and moderate rates of net $\mathrm{N}$

123 mineralization. Finally, Douglas-fir forest floors had intermediate $\mathrm{pH}$ and $\mathrm{Ca}$, high

124 bacterial:fungal ratios, high $\mathrm{N}$ concentrations and rates of net $\mathrm{N}$ mineralization and nitrification. 
In this study, we revisit the common garden experiment on Vancouver Island and

126 compare the forest floors that have developed under four tree species at one nutrient-rich, valley-

127 bottom site and one nutrient-poor, mid-slope site. We examine differences in forest floors among

128 tree species and the extent to which these differ according to the site. We measure rates of $\mathrm{N}$

129 mineralization and nitrification using ${ }^{15} \mathrm{~N}$ pool-dilution and apply quantitative PCR of microbial

130 genes involved in $\mathrm{N}$-cycling processes to explore interactions among microbial communities

131 (nitrifiers and denitrifiers) and rates of $\mathrm{N}$-cycling processes.

2. Materials and Methods

1342.1 Study location

135 We sampled two sites, as case studies rather than replicates, from the EP571 common 136 garden experiment on Vancouver Island: San Juan $\left(48^{\circ} 35^{\prime} \mathrm{N}, 124^{\circ} 12^{\prime} \mathrm{W}\right)$ and Fairy Lake

$137\left(48^{\circ} 35^{\prime} \mathrm{N}, 124^{\circ} 19^{\prime} \mathrm{W}\right)$, both located near Port Renfrew. The two sites were comparable in terms 138 of elevation (65-85 and 75-85 m, respectively), and were within the Sub-montane Very Wet 139 Maritime Coastal Western Hemlock variant (Prescott et al., 2000a). San Juan is a valley-bottom 140 site with understory largely composed of Rubus spectabilis Pursh (salmonberry) and Polystichum 141 munitum (Kaulf.) Presl. (swordfern), while Fairy Lake is a mid-slope site with understory 142 dominated by Gaultheria shallon Pursh (salal) and Vaccinium parvifolium Smith (red 143 huckleberry). Significantly higher $\mathrm{N}$ mineralization and nitrification rates and concentrations of $144 \quad \mathrm{P}$ and $\mathrm{K}$ were measured in forest floors at the San Juan site compared with the Fairy Lake site 145 (Prescott et al. 2000a), which were related to the differences in slope position and understory 146 vegetation. We selected these two study sites because of their contrast in terms of $\mathrm{N}$ cycling, to 147 enable us to test whether species effects on gross $\mathrm{N}$ cycling and functional genes would be 148 consistent across contrasting sites.

149 Replicate plots of each species (western red cedar, western hemlock, Douglas-fir, and

150 Sitka spruce) were planted in 1961, as a part of Experimental Project No. 571. The previous 151 forest cover of western hemlock, western red cedar, amabilis fir, and Sitka spruce had been clear152 cut and slash burned. The full experimental design contained 240.07 -ha plots at each site, with 15381 tree seedlings planted in three densities $(2.7,3.7$, and $4.7 \mathrm{~m})$; for the current study we sampled 154 the two densest (2.7-m spacing) plots of each species. We used this pre-existing experimental 155 design to determine if tree species differ in their dominant nutrient cycling characteristics 
between N-rich and N-poor sites.

\subsection{Soil sampling and soil physical and chemical analyses}

We focused on the F-layer of the forest floor. This is the layer in which the greatest differences in soil microbial communities of these tree species have previously been found (Grayston and Prescott, 2005), and where soil fungi and fauna are expected to be most abundant and active (Kurbatova et al., 2009). It also ensured that we were comparing the influence of tree species on microbial communities at the same stage of decay, as recommended by Prescott and Grayston (2013).

Composite samples were collected from nine randomly selected $450 \mathrm{~cm}^{2}$ samples of the F-layer in each plot in June of 2014. Brockett et al. (2012) showed that composite samples provide similar results to individually analyzed samples for plot-level values, albeit at a loss of information regarding spatial heterogeneity. Each composite forest floor sample was passed through a 2-mm mesh sieve and one 15 -g subsample was immediately removed for the ${ }^{15} \mathrm{~N}$ pooldilution analysis. The remaining bulk sample was stored at $-20^{\circ} \mathrm{C}$ for DNA extraction. For $\mathrm{pH}$ analysis, a 5-g field-moist subsample of forest floor was added to a small jar with $20 \mathrm{~mL}$ distilled

172 water, shaken for 30 minutes then measured with a $\mathrm{pH}$ meter. A subsample of field-moist forest

173 floor was also removed for $\mathrm{C}$ and $\mathrm{N}$ analysis. These samples were oven dried to $70^{\circ} \mathrm{C}$ for $48 \mathrm{~h}$,

174 ground using a mortar and pestle, and $5 \mathrm{mg}$ weighed into tin capsules and analyzed for $\mathrm{C}$ and $\mathrm{N}$

175 by high-temperature flash combustion using a Vario EL Cube elemental analyzer (Elementar 176 Americas Inc., Mount Laurel, NJ).

\subsection{Gross rates of ammonification and nitrification}

The ${ }^{15} \mathrm{~N}$ pool-dilution method (modified from Drury, 2008) was used to determine gross rates of ammonification and nitrification, with samples analyzed in triplicate. Six $15 \mathrm{~g}$

181 subsamples from each plot were passed through a 2-mm mesh sieve and transferred to $500 \mathrm{~mL}$ 182 glass Mason jars and sealed with parafilm $\left(\mathrm{n}=3\right.$ subsamples for both ${ }^{15} \mathrm{NH}_{4}{ }^{+}$and $\left.{ }^{15} \mathrm{NO}_{3}{ }^{-}\right)$. The 183 parafilm seal was punctured to enable gas exchange and maintain aerobic conditions. Samples 184 were incubated in the dark at room temperature for 24 hours prior to initial ${ }^{15} \mathrm{~N}$ treatments. These 185 treatments consisted of either: $4 \mathrm{~mL}$ of ${ }^{15} \mathrm{NH}_{4} \mathrm{Cl}$ solution (99 atom\%; Cambridge Isotope 186 Laboratories) or $4 \mathrm{~mL}$ of $\mathrm{K}^{15} \mathrm{NO}_{3}$ (99 atom\%; Cambridge Isotope Laboratories) added to the 
187 forest floor samples in each respective jar, which was an equivalent application rate of $12 \mu \mathrm{g} \mathrm{N}$

$188 \mathrm{~g}^{-1}$ forest floor. Labeled $\mathrm{N}$ was injected into the samples in $1 \mathrm{~mL}$ intervals four times over one 189 minute, and gently homogenized to ensure isotopic labeled $\mathrm{N}$ was applied uniformly throughout 190 the forest floor sample, and the parafilm seal was replaced.

i) Immediately after ${ }^{15} \mathrm{~N}$ addition and ii) 24 hours after ${ }^{15} \mathrm{~N}$ addition, a 5-g forest floor 192 subsample was removed from each Mason jar, this subsample was added to $100 \mathrm{~mL}$ of $2.0 \mathrm{M}$ $193 \mathrm{KCl}$, shaken for 1 hour, and filtered through glass fiber filter paper (Fisher Inc.). $10 \mathrm{~mL}$ of the $194 \mathrm{KCl}$ extract were analyzed for $\mathrm{NH}_{4}-\mathrm{N}$ and $\mathrm{NO}_{3}-\mathrm{N}$ using a flow injection analyzer (Lachat;

195 Quickchem 8000) at the Environmental Engineering Department at the University of British 196 Columbia. The remainders of the extracts were used for microdiffusion of ${ }^{15} \mathrm{NH}_{4}-\mathrm{N}$ and ${ }^{15} \mathrm{NO}_{3}-\mathrm{N}$ 197 with the use of acid traps, and the sequential addition of $\mathrm{MgO}$ and Devarda's alloy according to 198 the protocol developed by the International Atomic Energy Agency (IAEA, 2001). Acid traps

199 were dried, packaged in tin cups, and sent to the University of Saskatchewan Isotope Laboratory 200 for stable isotope ratio analysis using a Costech ECS4010 elemental analyzer coupled to a Delta 201 V mass spectrometer with a Conflo IV interface. Net rates of ammonification were calculated as 202 the difference in $\mathrm{NH}_{4}{ }^{+}$between the incubated samples and the initial soil extractions at the start 203 of the incubation. Net nitrification was calculated as the difference in $\mathrm{NO}_{3}{ }^{-}$between the initial 204 and incubated samples. The gross rates of ammonification, nitrification and microbial consumption were calculated following Hart et al. (1994).

\subsection{Microbial biomass determination}

208 Microbial biomass nitrogen (MBN) and microbial biomass carbon (MBC) were 209 determined using a modified chloroform-fumigation extraction (Brookes et al., 1985). Briefly, $210100 \mathrm{~mL}$ of $2 \mathrm{M} \mathrm{KCl}$ was used in lieu of $40 \mathrm{~mL}$ of $0.5 \mathrm{M} \mathrm{K}_{2} \mathrm{SO}_{4}$ for extractions (Verchot et al., 211 1999). $20 \mathrm{~mL}$ extracts were analyzed for total organic C (TOC) and total N (TN) on a Shimadzu 212 5000A TOC analyzer at the Analytical Services Laboratory of the University of Alberta. The 213 additional remaining extractant was used for acid diffusion traps, identical to the above protocol 214 for the ${ }^{15} \mathrm{~N}$ pool-dilution method. To determine if microbial communities were immobilizing $\mathrm{N}$ 215 during the course of the incubation we assessed $\mathrm{MBN}$ and $\mathrm{MBC}$ in ${ }^{15} \mathrm{~N}-\mathrm{NH}_{4}$ and ${ }^{15} \mathrm{~N}-\mathrm{NO}_{3}$ added 216 samples at the end of the pool-dilution experiment, as well as from unfertilized soil samples. 
219 forest floor using the MoBio Power Soil DNA isolation kit (MoBio Laboratories, Inc., Carlsbad, 220 CA, USA). DNA quality and concentration was measured using a nanodrop spectrophotometer 221 (Thermo Fisher Scientific Inc., Wilmington, DE, USA) and electrophoresis in agarose gels (1\% $222 \mathrm{w} / \mathrm{v}$ in TAE), then stored at $-20^{\circ} \mathrm{C}$ prior to amplification.

Quantitative PCR (qPCR) was used to quantify gene copy numbers. Reactions were 224 carried out with an Applied Biosystems ${ }^{\circledR}$ StepOnePlus ${ }^{\text {TM }}$ real-time PCR system. Each $20 \mu 1$ 225 reaction contained $10 \mu \mathrm{l}$ of SybrGreen (2x) PCR Master Mix (Life Technologies Corp., Carlsbad, $226 \mathrm{CA}$, USA), $0.5 \mu \mathrm{l}$ of each primer, $250 \mathrm{ng}^{-1} \mathrm{l}^{-1}$ bovine serum albumin (BSA), and $1 \mu \mathrm{l}$ of DNA 227 template. Table 1 shows primer sequences for qPCR assays. PCR conditions for AOA amoA, $228 \mathrm{AOB}$ amoA were $10 \mathrm{~min}$ at $95^{\circ} \mathrm{C}$, followed by 40 cycles of $95^{\circ} \mathrm{C}$ for $30 \mathrm{~s}, 30 \mathrm{~s}$ at $57^{\circ} \mathrm{C}$, and $72^{\circ} \mathrm{C}$ 229 for $1 \mathrm{~min}$, and $10 \mathrm{~s}$ at $80^{\circ} \mathrm{C}$. Triplicate $10 \mathrm{x}$ standard curves ranged from $10^{2}$ to $10^{7}$ copy numbers 230 of AOA and AOB amoA in linearized plasmids. PCR conditions for nirK and nirS were 10 min at $23195^{\circ} \mathrm{C}$ and 40 cycles of $95^{\circ} \mathrm{C}$ for $1 \mathrm{~min}, 60^{\circ} \mathrm{C}$ for $1 \mathrm{~min}$ and $72^{\circ} \mathrm{C}$ for $1 \mathrm{~min}$, with fluorescence 232 quantified at extension (Levy-Booth and Winder, 2010). The standard curves for nirS and nirK 233 used a triplicate 10-fold serial dilutions of $10^{1}$ to $10^{7}$ gene copies from Pseudomonas aeruginosa 234 (ATCC 47085) and Pseudomonas chlororaphis (ATCC 13985) genomic DNA, respectively.

235 Bacterial $16 \mathrm{~S}$ rRNA PCR conditions were 5 min at $95^{\circ} \mathrm{C}$, followed by 40 cycles of $95^{\circ} \mathrm{C}$ for $30 \mathrm{~s}$, $23630 \mathrm{~s}$ at $57^{\circ} \mathrm{C}$, and $72^{\circ} \mathrm{C}$ for $1 \mathrm{~min}$, and $10 \mathrm{~s}$ at $80^{\circ} \mathrm{C}$. Florescence quantification occurred during 237 annealing. Triplicate standard curves were run using a 10x dilution of $10^{2}$ to $10^{7}$ amplified $16 \mathrm{~S}$ 238 rRNA in linearized plasmids. PCR conditions for fungal ITS were $10 \mathrm{~min}$ at $95^{\circ} \mathrm{C}$, followed by 23940 cycles of $95^{\circ} \mathrm{C}$ for $1 \mathrm{~min}, 30 \mathrm{~s}$ at $53^{\circ} \mathrm{C}, 50 \mathrm{~s}$ at $72^{\circ} \mathrm{C}$ and $10 \mathrm{~s}$ at $80^{\circ} \mathrm{C}$. Fluorescence was read 240 at $80^{\circ} \mathrm{C}$ to reduce the formation of non-target and primer self-complementation structures.

241 Triplicate standard curves for fungal ITS quantification were constructed using 10x dilutions 242 between $10^{3}$ to $10^{9}$ ITS copies amplified from soil and Aspergillus citrisporus genomic DNA.

243 Standard curve ranges are indicative of lower and upper limits of detection, respectively. All 244 qPCR analyses were run in duplicate.

\subsection{Statistical analyses}

247 At each site one composite forest floor sample from the two replicate plots for each tree 248 species was sampled $(n=2)$. The influences of tree species and sites on forest floor chemistry, 
microbial biomass $\mathrm{C}$ and $\mathrm{N}$, process rates and gene abundances were evaluated using two-way

250 permutational analysis of variance (with 999 permutations). Permutational analysis of variance

251 was used to address the low sample sizes in this study (Andersen and Legendre, 1999) with tree

252 species and site as fixed effects. Microbial gene abundances were $\log _{10}$ transformed prior to two-

253 way permutational analysis of variance (with 999 permutations). We used multiple linear

254 regressions to determine which environmental variables were the best predictors of $\mathrm{N}$

255 transformations on standardized data (decostand function in the vegan package in $\mathrm{R}$ (Oksanen et

256 al., 2013)). Rates of $\mathrm{N}$ transformations, including gross and net ammonification and nitrification,

257 were related to all potentially regulating parameters using multiple linear regressions, following

258 the removal of collinear variables. Model selection was based on stepwise variable selection with

259 Akaike's Information Criterion (AIC), whereby the lowest value indicates the model with the

260 highest explanatory power.

261 Redundancy analysis (RDA), a form of constrained ordination that determines how much

262 of the variation from one set of variables explains the variation in another set of variables, was

263 performed to test relationships between site and forest floor parameters and gene abundances

264 (vegan package in $\mathrm{R}$ ). Forward selection of explanatory variables for RDA was carried out using

265 the packfor function using the method recommended by Blanchet et al. (2008). The significance

266 of the RDA model and its individual terms were calculated using Monte-Carlo tests with 10000

267 permutations. All analyses were conducted with R v. 2.15.3 (R Core Team, 2013).

269 3. Results

2703.1 Forest floor $\mathrm{pH}, \mathrm{C}$ and $\mathrm{N}$

271 There were no significant differences in $\mathrm{pH}$, although Sitka spruce and western red cedar

272 had the highest average $\mathrm{pH}$ values (Table 2). Concentrations of total $\mathrm{C}$ and $\mathrm{N}$ also did not

273 significantly differ between forest floors under the four tree species or at the two sites (Table 3).

274 However, forest floor C:N ratio was significantly lower $(p=0.02)$ at the San Juan (nutrient-rich)

275 site $(36.5 \pm 1.1)$ than at Fairy Lake (nutrient-poor) (42.2 \pm 1.5$)$. C:N ratio also differed among

276 tree species, with hemlock forest floors having significantly higher $\mathrm{C}: \mathrm{N}$ ratio $(43.3 \pm 2.3)$ than

277 Sitka spruce $(36.4 \pm 2.1 ; p=0.018)$ and Douglas-fir $(36.6 \pm 1.2 ; p=0.015)$. There were no

278 significant species-by-site interaction effects, indicating consistent tree species effects on C:N

279 ratios across sites. 


\subsection{Microbial biomass $C$ and $N$}

Microbial biomass C (MBC) differed among tree species across both sites and was significantly lower in forest floors at San Juan than Fairy Lake (Figure 1, Table 3). Significant

284 species-by-site interaction indicated that influences of tree species on MBC differed between the two sites $(p=0.03)$. At Fairy Lake, Sitka spruce had lower MBC than other species whereas cedar had lower MBC than other tree species at San Juan (Figure 1). Microbial biomass N $(\mathrm{MBN})$ did not differ significantly between sites $(p=0.89)$ or among tree species across sites (Table 3, $p=0.39$ ), but at San Juan, Douglas-fir had higher MBN than other species (Figure 1). Microbial C:N ratios did not differ significantly between sites or tree species, although there was a tendency for lower microbial C:N at San Juan (Figure 1, $p=0.10$ ).

\subsection{Microbial gene abundance}

Bacteria $16 S$ rRNA gene abundance was significantly greater in forest floors from San

294 Juan than from Fairy Lake (Table 3, $p=0.01$ ), and differed significantly among tree species

295 (Table 3, $p=0.05$ ) with no species-by-site interaction. Bacterial genes were more abundant in

296 forest floors of western red cedar at both sites, with hemlock or spruce having the lowest 297 abundance depending on the site (Figure 2). Fungal ITS abundance did not differ between sites ( $p$ $298=0.55)$ or tree species $(p=0.89)$. AOA amoA had the most pronounced site effect of any of the 299 microbial genes quantified in this study, with San Juan having several orders of magnitude more 300 AOA amoA genes than Fairy Lake $(p=0.01)$, but no species effects. AOB amoA genes were 301 more abundant at San Juan than at Fairy Lake, but within the same order of magnitude $(p=0.10)$. 302 The abundance of the Cu-nitrite reductase (nirK) gene did not differ by site $(p=0.19)$, or tree 303 species $(p=0.13)$, although hemlock tended to have the lowest gene abundance. In contrast, Cd304 nitrite reductase (nirS) genes were significantly more abundant in forest floor at San Juan than at 305 Fairy Lake $(p=0.02)$, but did not differ by tree species $(p=0.27)$.

\subsection{Gross and net $N$ ammonification and nitrification rates}

308 Gross ammonification rates were significantly higher in forest floors at San Juan than at 309 Fairy Lake (Figure 3a), with mean rates of 32.9 and $19.4 \mathrm{mg} \mathrm{N} \mathrm{g}^{-1}$ soil (dw) day ${ }^{-1}$, respectively. 310 A highly significant trees species effect on gross ammonification was observed with gross 
311 ammonification under western red cedar being significantly greater than under Douglas-fir $(p=$

$3120.03)$, hemlock $(p=0.006)$ and Sitka spruce $(p=0.03)$. Gross ammonium $\left(\mathrm{NH}_{4}{ }^{+}\right)$consumption

313 was significantly higher in forest floors from San Juan than Fairy Lake $(p=0.002)$, and was

314 significantly greater in forest floors under cedar than the other species (Figure $3 b$ ). Net

315 ammonification rates were mostly negative, indicating net immobilization of $\mathrm{NH}_{4}{ }^{+}$, with

316 occasional positive mineralization occurring only in Sitka spruce at San Juan (Figure 3c). San

317 Juan forest floors had higher (i.e. less negative) rates of net ammonification than Fairy Lake

318 forest floors $(p=0.01)$, and net ammonification rates differed among tree species $(p=0.05)$.

319 Rates of gross nitrification, nitrate consumption and net nitrification did not differ

320 between species, but did differ between sites with slightly more $\mathrm{N}$ transformed at Fairy Lake

321 than San Juan $(p<0.01)$. At Fairy Lake, western red cedar had the highest rates of gross

322 nitrification, which significantly differed from hemlock and Sitka spruce, but not from Douglas-

323 fir. Douglas-fir and Sitka spruce had the highest and similar rates of nitrate consumption,

324 followed by western red cedar, spruce, and hemlock at Fairy Lake. At San Juan, Sitka spruce had

325 the highest rates of gross nitrification. Douglas-fir, western red cedar, and hemlock all had

326 negligible rates of gross nitrification and nitrate consumption. Net nitrification rates were

327 negative, indicating net nitrate immobilization in all plots except Sitka spruce at San Juan

328 (Figure 3f).

329

\subsection{Relationships between $N$ ammonification and nitrification rates and microbial parameters}

In general, we had greater explanatory power for ammonification rates than nitrification rates (Table 4). Gross ammonification was best explained by the total number of bacterial $16 \mathrm{~S}$ rRNA and fungal ITS genes. Gross $\mathrm{NH}_{4}{ }^{+}$consumption was best explained by gross

334 ammonification, $\mathrm{pH}$, forest floor $\mathrm{C}: \mathrm{N}$ ratio, and microbial biomass $\mathrm{C}: \mathrm{N}$ ratio. Net ammonification was best explained by forest floor $\mathrm{pH}$ and $\mathrm{C}: \mathrm{N}$ ratios and microbial biomass $\mathrm{C}: \mathrm{N}$

336 ratios. Gross nitrification was best explained by microbial biomass C:N ratios and AOA amo $A$ 337 gene. Gross $\mathrm{NO}_{3}{ }^{-}$consumption was best explained by net ammonification, gross nitrification, 338 microbial biomass $\mathrm{C}: \mathrm{N}$ ratios, bacterial $16 \mathrm{~S}$ and $\mathrm{AOA}$ and $\mathrm{AOB}$ amoA genes. Net nitrification 339 rates were best explained by net ammonification, microbial biomass $\mathrm{C}: \mathrm{N}$ ratios, bacterial 16S, 340 and AOA and AOB amoA genes. The sum of AOA and AOB gene abundances showed a strong, 341 positive relationship with the sum of the abundance of nitrite reductase genes (nirK and nirS) 
342 (Figure 4). Redundancy analysis showed clear separation of the two sites largely due to

343 differences in forest floor $\mathrm{C}: \mathrm{N}$ ratio and $\mathrm{pH}$, but no clear grouping of microbial abundance

344 patterns according to tree species (Figure 5). Fairy Lake was associated with high C:N ratio, and

345 San Juan with higher microbial gene abundance for AOA and AOB amoA, nirK, nirS, and $16 S$.

\section{4. Discussion}

348 The relationships between rates of production and consumption of $\mathrm{N}$ and microbial parameters uncovered in this study provide insights into the mechanisms underlying differences in $\mathrm{N}$ cycling and availability in forest floors. The prominence of forest floor $\mathrm{C}: \mathrm{N}$ ratio in the relationships indicate that site $\mathrm{N}$ status exerts a dominant influence on $\mathrm{N}$ cycling. The proportion of mineralized $\mathrm{N}$ taken up by microbial biomass, rather than the gross mineralization rate, appeared to be the primary driver of $\mathrm{N}$ release, consistent with conclusions of Mooshammer et al. (2014).

354 While gross ammonification was influenced by the abundance of bacteria and fungi (i.e. overall saprotrophic activity), consumption of the mineralized $\mathrm{NH}_{4}{ }^{+}$depended on microbial demand for $\mathrm{N}$, as indicated by microbial C:N ratio. This is consistent with forest floors at these sites having different rates of $\mathrm{N}$ mineralization and nitrification despite similar rates of litter decomposition and C mineralization (Prescott et al., 2000). The strong relationships between rates of most $\mathrm{N}$ transformation processes and microbial $\mathrm{C}: \mathrm{N}$ ratio indicate that the $\mathrm{N}$ status of microbes, i.e. the degree to which $\mathrm{N}$ is available excess to their needs, rather than their biomass or activity level, determined the amount of $\mathrm{NH}_{4}{ }^{+}$that remained available in the forest floor. High microbial N status (i.e. low microbial C:N ratio) led to a smaller proportion of the $\mathrm{NH}_{4}{ }^{+}$being consumed by microbes, and the resulting 'excess' $\mathrm{NH}_{4}{ }^{+}$stimulated nitrifying organisms (as indicated by the relationships between microbial biomass $\mathrm{C}: \mathrm{N}$ ratios and $a m o A$ gene abundances). Nitrate production then creates conditions conducive to denitrifying organisms as indicated by the relationship between $\mathrm{AOA}$ and $\mathrm{AOB}$ gene abundances and abundance of nitrite reductase genes

367 (nirK and nirS).

The manner in which these interrelationships between site conditions, soil microorganisms and $\mathrm{N}$

370 cycling processes play out at the two study sites is illustrated in Figure 6. Despite similar rates of

371 decomposition and $\mathrm{C}$ mineralization between sites, the high $\mathrm{C}: \mathrm{N}$ ratio in organic matter and

372 microbes at Fairy Lake causes all of the mineralized $\mathrm{NH}_{4}{ }^{+}$to be consumed by microbes and 
373 plants. In contrast, at San Juan, the low C:N ratio of the organic matter causes more $\mathrm{N}$ to be 374 mineralized per unit $\mathrm{C}$ mineralized, and only a portion of this is consumed by microbes and 375 vegetation. The resulting accumulation of $\mathrm{NH}_{4}{ }^{+}$stimulates ammonia-oxidizers (as evident in the 376 higher microbial gene abundance for AOA and AOB amoA), which liberate $\mathrm{N}$ in the form of 377 nitrate. Some of this nitrate is consumed by microbes and plants, and some is used by denitrifiers, as evident in the detection of higher microbial gene abundance for nirK, and nirS in San Juan forest floors.

For many of the variables in this study, the influence of site $\mathrm{N}$ status on $\mathrm{N}$ cycling processes was greater than the influence of tree species. Observed gross ammonification rates support earlier findings of greater net $\mathrm{N}$ mineralization rates and higher bacterial:fungal ratio in forest floors at nutrient-rich, valley-bottom sites (including San Juan) than at nutrient-poor, midslope sites (including Fairy Lake) (Prescott et al., 2000a; Grayston and Prescott, 2005). Microbial gene abundances were also strongly affected by site, with forest floors from the San Juan site have a higher potential for nitrification and denitrification than those from Fairy Lake.

Forest floor $\mathrm{C}: \mathrm{N}$ ratios were the primary feature of site influence on microbial biomass, gene abundance and $\mathrm{N}$ transformations. This is consistent with earlier findings that rates of $\mathrm{N}$ mineralization in forest floors along a site fertility gradient in Douglas-fir stands were most closely related to forest floor $\mathrm{C}: \mathrm{N}$ ratios, with net mineralization being appreciable only at sites where the forest floor C:N ratio was less than 35. Similarly, Högberg et al. (2007) found forest floor $\mathrm{C}: \mathrm{N}$ ratios to be as important as $\mathrm{pH}$ and base cations in predicting microbial community composition in forest floors in a boreal Fennoscandian forest ecosystem, while Chen and Högberg (2007) found negative correlations between fungal:bacteria ratios, forest floor C:N ratios and gross mineralization rates in forest floors. Bates et al. (2011) found soil C:N ratio to be the best predictor for archaeal relative abundances, with higher $\mathrm{C}: \mathrm{N}$ ratios leading to higher archaeal relative abundances.

Tree species effects were smaller than site effects, and were more pronounced for $\mathrm{NH}_{4}^{+}$ transformations than for $\mathrm{NO}_{3}{ }^{-}$transformations. Western red cedar had consistently high abundance of $16 \mathrm{~S}$ and AOA amoA at both sites, and higher rates of gross ammonification and

402 consistent with previous studies highlighting the different $\mathrm{N}$ transformation pattern and microbial 403 community structure in western red cedar forest floors (Turner and Franz, 1985; Prescott et al., 
2000a; Prescott and Grayston, 2005). Douglas-fir and Sitka spruce had similar abundances of all targeted genes, which did not significantly differ from each other. Some tree species effects appeared to depend on site $\mathrm{N}$ status. For example, Sitka spruce and western hemlock differed in rates of net ammonification, but only at the nutrient-poor site, Fairy Lake. The data from this study support both direct effects of tree species on soil $\mathrm{N}$ cycling and soil microbial communities, but also highlight the context-dependency of tree species effects (Prescott and Vesterdal 2013).

The positive correlation between gross ammonification rate and abundance of bacterial $16 \mathrm{~S}$ rRNA genes suggests an important role of bacteria in ammonification, which aligns with current thinking about N-cycling processes (Laverman et al., 2001, Kowalchuk and Stephen, 2001, Wallenstein et al., 2006). The significantly positive correlations between the abundance of AOA amoA genes and rates of both gross and net nitrification indicate that nitrification in these forest floors is modulated primarily by archaeal ammonia-oxidation, with AOB playing a negligible role. Although archaea are considered to contribute little to soil microbial biomass (Gattinger et al., 2002; Bardgett and Griffiths, 1997), archaea in forest soils can have a functional role in N cycling akin to a keystone species (Prosser and Nicol, 2008; Verhamme et al., 2011). AOA are generally more abundant than AOB in acidic forest soils (Petersen et al., 2012) and AOA can have higher ammonia-oxidation rates relative to $\mathrm{AOB}$ under similar $\mathrm{N}$ availabilities (Wertz et al., 2012). The strong, positive relationship between the abundance of nitrite reductase genes (nirK, nirS) and the sum of AOA and AOB indicates that the genetic potential for denitrification in these forest floors was strongly influenced by ammonia oxidizer abundance. We measured gene abundance rather than directly assessing activity associated with specific genes; in other studies, gene abundances have shown a high degree of correlation with substrate concentrations and process rates (McGill et al., 2006; Wertz et al., 2009; Penton et al., 2013; Levy-Booth et al., 2014). Recent studies have characterized the comammox Nitrosospira species which contain enzymes that catalyze complete nitrification (van Kessel et al., 2015 and Daims et al., 2015), but these organisms were not considered in this study.

Bacterial $16 S$ and nirK varied amongst tree species, which suggests that tree species foster different abundances of denitrifying bacteria, in addition to the elevated AOA amoA in western red cedar plots. AOA $a m o A$ can oxidize ammonia via an alternate pathway that requires less oxygen than the bacterial (AOB amoA) channel, which enables ammonia oxidation in anoxic 
435 soils (Schleper and Nicol, 2010; Levy-Booth et al., 2014). Similarly, organisms that contain the

436 gene nirS often do not contain nirK, which suggests that tree species-specific soil microbial

437 communities are associated with specific denitrifying bacteria (Levy-Booth et al., 2014).

438 Consistent with previous studies of forest floor microbial communities associated with these tree

439 species (Grayston and Prescott, 2005; Turner and Franz, 1985), we found cedar forest floors to

440 be more bacteria-dominated $(16 S)$ while forest floors of all four tree species were similar in

441 fungal abundance (fungal ITS).

The net $\mathrm{N}$ transformation rates presented here were derived from the 24-hour gross- $\mathrm{N}$

444 incubations, not a standard 28-day incubation for rate of net $\mathrm{N}$ mineralization such as in the

445 previous study of forest floor $\mathrm{N}$ dynamics in the common garden experiment (Prescott et al.,

446 2000a). The short-term incubation study found tree species differences in $\mathrm{N}$ ammonification

447 rates, but these were overshadowed by site effects. This is consistent with results of the longer-

448 term incubations (Prescott et al., 2000a), although the values should not be directly compared,

449 and more studies are needed to confirm the patterns. Nevertheless, this study demonstrates that a)

450 differences between tree species and sites are discernible with these methods, and b) insights into

451 the linkages between forest floor physico-chemical parameters, microbial gene abundance and

452 biogeochemical cycling can be gained using these methods.

\section{5. Conclusions}

455 Quantification of key microbial marker genes involved in biogeochemical

456 transformations were used to explore mechanistic links between site factors, tree species and $\mathrm{N}$

457 cycling processes. Rates of $\mathrm{N}$ transformation and microbial gene abundances were higher at the

458 San Juan site, which had higher forest floor C:N ratios, higher microbial gene abundances related

459 to nitrification and denitrification, and higher gross $\mathrm{N}$ transformation rates. Differences between

460 the sites were related to site $\mathrm{N}$ status, as reflected in $\mathrm{C}: \mathrm{N}$ ratios of the forest floor, and were more

461 closely tied to rates of $\mathrm{N}$ consumption rather than gross mineralization. The relative contributions

462 of AOA and AOB to gross and net nitrification in forests were mainly influenced by site $\mathrm{N}$

463 status. Tree species influenced gross and net ammonification and $\mathrm{NH}_{4}{ }^{+}$consumption. Western

464 red cedar forest floors were the most distinct of the four tree species, with highest rates of $\mathrm{NH}_{4}{ }^{+}$

$465 \mathrm{~N}$ transformation, and the most distinctive forest floor microbial communities in terms of $16 \mathrm{~S}$ 
and nirK gene abundances. The coupling of techniques for assessing ecosystem process rates

467 with molecular techniques, such as functional gene abundances, can provide a greater mechanistic understanding of links between tree species and $\mathrm{N}$ transformation processes, as

469 demonstrated in this study.

\section{Acknowledgements}

472 The authors would like to thank Israel Del Toro for field assistance, Mary Berbee for providing 473 Aspergillis DNA, and Andy Smith and John Healey for comments on study design. The research 474 was funded by NSERC grants to CEP and SJG, and a FONASO fellowship to RRR. The authors 475 declare no conflict of interest.

\section{Literature Cited}

Allison, S.D. 2005. Cheaters, diffusion and nutrients constrain decomposition by microbial enzymes in spatially structured environments. Ecology Letters 8, 627-635.

Andersen, M.J., and Legendre, P. 1999. An empirical comparison of permutation methods for tests of partial regression coefficients in a linear model. Journal of Statistical Computation and Simulation 62:271-303.

Baker G.C., et al. 2003. Review and re-analysis of domain-specific 16S primers. Journal of Microbiological Methods. 55: 541-555.

Balser, T.C., Firestone, M.K. 2005. Linking microbial community composition and soil processes in a California annual grassland and mixed-conifer forest. Biogeochemistry 73, 395-415.

Bardgett, R.D. and Griffiths, B.S. 1997. Ecology and biology of soil protozoa, nematodes, and microarthropods. In: Modern Soil Microbiology. J.D. van Elsas, J.T. Trevors, E.M.H. Wellington (Eds.), Marcel Dekker, New York. pp. 129-163

Bates, S.T., et al. 2011. Examining the global distribution of dominant archael populations in soil. The ISME Journal. 5: 908-917.

Bengtsson, G., et al. 2003. Gross nitrogen mineralization-, immobilization-, and nitrification

496 Binkley, D. and Giardina, C.1998. Why do tree species affect soils? The Warp and Woof of tree- 
soil interactions. Biogeochemistry 42: 89-106.

Blanchet, F.G., et al. 2008. Forward selection of explanatory variables. Ecology. 89: 2623-2632.

Braker, G., et al.1998. Development of PCR primer systems for amplification of nitrite reductase genes (nirK and nirS) to detect denitrifying bacteria in environmental samples. Applied Environmental Microbiology. 64: 3769-3775.

Booth, M.S., et al. 2005. Controls on nitrogen cycling in terrestrial ecosystems: a synthetic analysis of literature data. Ecological Monographs 75: 139-157.

Brockett B.F.T., et a.. 2012. Soil moisture is the major factor influencing microbial community structure and enzyme activities across seven biogeoclimatic zones in western Canada. Soil Biology and Biochemistry 44: 9-20.

Brooks, P.D., et al. 1989. Diffusion method to prepare soil extracts for automated nitrogen-15 analysis. Soil Science Society of America Journal 53: 1707-1711.

Chu, H., Grogan, P. 2010. Soil microbial biomass, nutrient availability and nitrogen

Dairns, H. et al. 2015. Complete nitrification by Nitrospira bacteria. Nature. 528, 504-509.

Drury, C.F., et al. 2008. Chapter 38: Nitrification techniques for soils. In Soil Sampling and Methods of Analysis, Second Edition. Edited by M.R. Carter and E.G. Gregorich. DOI:

Brookes, P. C., et al. 1985. Chloroform fumigation and the release of soil nitrogen: a rapid direct extraction method to measure microbial biomass nitrogen in soil. Soil Biology and Biochemistry 17:837-842. mineralization potential among vegetation-types in a low arctic tundra landscape. Plant and Soil. 329, 411-420.

\subsection{1/9781420005271.ch38}

Fierer, N., et al. 2005. Assessment of soil microbial community structure by use of taxonspecific quantitative PCR assays. Applied and Environmental Microbiology 71, 41174120.

Gardes, M., and Bruns, T.D. 1993. ITS primers with enhanced specificity for basidiomycetesapplication to the identification of mycorrhizae and rusts. Molecular Ecology. 2: 113118.

Gattinger, A., et al. 2002. Microbial community structure varies in different soil zones of a potato field. Journal of Plant Nutrition and Soil Science 165: 421-428.

Grayston, S.J. and C.E. Prescott. 2005. Microbial communities in forest floors under four tree 
species in coastal British Columbia. Soil Biology and Biochemistry 37: 1157-1167.

Hart, S.C., et al. 1994. Nitrogen mineralization, immobilization, and nitrification. In: Weaver, R.W., Angle, S., Bottomley, P., Bezdicek, D., Smith, S., Tabatabi, A., and Wollum, A. (Eds.). Methods of Soil Analysis: Part 2. Microbiological and Biochemical Properties. Soil Science Society of America, Madison, WI, pp. 985-1018.

Hobbie, S.E., et al. 2006. Tree species effects on decomposition and forest floor dynamics in a common garden. Ecology 87, 2288-2297.

Högberg, M.N., et al. 2007. Is microbial community composition in boreal forest soils determined by $\mathrm{pH}, \mathrm{C}-\mathrm{to}-\mathrm{N}$ ratio, the trees, or all three? Oecologia 150:590-601.

Högberg, M.N., et al. 2007.Gross nitrogen mineralisation and fungi-to-bacteria ratios are negatively correlated in boreal forests. Biology and Fertility of Soils 44:363-366. DOI: $10.1007 / \mathrm{s} 00374-007-0215-9$

Högberg, M.N., et al. 2013. Soil microbial community indices as predictors of soil solution chemistry and N leaching in Picea abies (L.) Karst. forests in S. Sweden. Plant and Soil $372,507-522$.

Kowalchuk, G.A., and Stephen, J.R. 2001. Ammonia-oxidizing bacteria: A model for molecular microbial ecology. Annual Reviews in Microbiology. 55: 485-529.

Lauber, C.L., et al. 2008. The influence of soil properties on the structure of bacterial and fungal communities across land-use types. Soil Biology and Biochemistry 40: 2407-2415.

Laverman, A.M., et al. 2001. Spatiotemporal stability of an ammonia-oxidizing community in a nitrogen-saturated forest soil. Microbial ecology 42:35-45.

Leckie, S.E., et al. 2004. Characterization of humus microbial communities in adjacent forest types that differ in nitrogen availability. Microbial Ecology 48: 29-40.

Leininger, S., et al. 2006. Archaea predominate among ammonia-oxidizing prokaryotes in soils. Nature 442, 806-809.

LeJon, D.P.H., et al. 2005. Microbial Community Structure and Density Under Different Tree Species in an Acid Forest Soil (Morvan, France). Microbial Ecology 50: 614-625.

Levy-Booth, D.J., Winder, R.S. 2010. Quantification of nitrogen reductase and nitrite reductase genes in soil of thinned and clear-cut Douglas-fir stands by using real-time PCR. Applied and Environmental Microbiology 76, 7116-7125.

Levy-Booth., et al. 2014. Microbial functional genes involved in nitrogen fixation, nitrification 
and denitrification in forest ecosystems. Soil Biology and Biochemistry 75, 11-25.

560 Lovett, G.M., et al. 2002. Control of nitrogen loss from forested watersheds by soil carbon:nitrogen ratio and tree species composition. Ecosystems 5:0712-0718.

Malchair, S. and Carnol, M. 2009. Microbial biomass and C and N transformations in forest floors under European beech, sessile oak, Norway spruce, and Douglas-fir ant four temperate forest sites. Soil Biology and Biochemistry 41: 831-839.

Malchair, S. and Carnol, M. 2013. AOB community structure and richness under European beech, sessile oak, Norway spruce and Douglas-fir at three temperate forest sites. Plant and Soil Science 366: 521-535.

Mengistu, S.G., et al. 2014. Searching for similarity in topographic controls on carbon, nitrogen and phosphorus export from forested headwater catchments. Hydrological Processes 28:3201-3216.

Mooshammer, M., et al. 2014. Adjustment of microbial nitrogen use efficiency to carbon: nitrogen imbalances regulates soil nitrogen cycling. Nature Communications 5, doi: $10.1038 /$ ncomms4694.

Muyzer G., et al. 1995. Phylogenetic relationships of Thiomicrospiraspecies and their identification in deep-sea hydrothermal vent samples by denaturing gradient gel electrophoresis of 16S rDNA fragments. Archives of Microbiology 164:165-172.

Petersen, D.G., et al. 2012. Abundance of microbial genes associated with nitrogen cycling as indices of biogeochemical process rates across a vegetation gradient in Alaska. Environmental Microbiology 14:993-1008.

Prescott, C. E. 2014. The scientific value of long-term field trials in forest soils and nutrition research: An opportunist's perspective. Canadian Journal of Soil Sciene 94: 255-262.

Prescott, C.E., et al. 2000a. Nutrient concentrations and nitrogen mineralization in forest floors of single species conifer plantations in coastal British Columbia. Canadian Journal of Forest Research 30:1341-1352.

Prescott, C.E., et al. 2000b. Nitrogen turnover in forest floors of coastal Douglas-fir at sites differing in soil nitrogen capital. Ecology 81:1878:1886.

Prescott, C.E., et al. 2000c. Humus in northern forests: friend or foe? Forest Ecology and Management 133:23-36.

Prescott C.E. and Grayston S.J. 2013. Tree species influence on microbial communities in litter 
Prescott, C.E. and Preston, C.M. 1994. Nitrogen mineralization and decomposition in forest

and soil: current knowledge and research needs. Forest Ecology and Management 309: 19-27. Special Issue from Eurosoil Session S10.3. 'Influences of Tree Species on Forest Soils', 2012, Bari, Italy. floors in adjacent plantations of western red cedar, western hemlock, and Douglas-fir. Canadian Journal of Forest Research 24: 2424-2431.

Prescott, C.E. and Vesterdal, L. 2013. Tree species effects on soils in temperate and boreal forests: emerging themes and research needs. Forest Ecology and Management 309: 1-3. Prescott, C.E., and Vesterdal, L., 2005. Effects of British Columbia tree species on forest floor chemistry. Chapter 2. In: Binkley, D., Menyailo, O. (Eds.), Tree Species Effects on Soils. Implications for Global Climate Change. Springer, Dordrecht, The Netherlands, pp. 1729.

Priha, O. and Smolander, A. 1997. Microbial biomass and activity in soil and litter under Pinus sylvestris, Picea abies and Betula pendula at originally similar field afforestation sites. Biol Fertil Soils 24: 45-51.

Prosser J.I. and Nicol G.W. 2008. Relative contributions of archaea and bacteria to aerobic ammonia oxidation in the environment. Environmental Microbiology 10: 2931-2941.

Rousk, J., et al. 2009. Contrasting Soil pH Effects on Fungal and Bacterial Growth Suggest Functional Redundancy in Carbon Mineralization. Applied and Environmental Microbiology 75: 1589-1596.

Seibert, J., et al. 2007. Topographical influences on soil properties in boreal forests. Geoderma 141:139-148.

Ste-Marie, C., Paré, D. 1999. Soil, pH and N availability effects on net nitrification in the forest floors of a range of boreal forest stands. Soil Biology and Biochemistry 31, 1579-1589.

Turner, D.P., and Franz, E.H. 1985. The influence of western hemlock and western redcedar on microbial numbers, nitrogen mineralization, and nitrification. Plant Soil 88, 259-267.

van Kessel, M.A.H.J., et al. 2015. Complete nitrification by a single microorganism. Nature. 528, 555-559.

Verchot, L.V., Holmes, Z., Mulon, L., et al. 2001. Gross vs. net rates of N mineralization and nitrification as indicators of functional differences between forest types. Soil Biology and 
Biochemistry 33: 1889-1901.

621 Verhamme, D.T., Prosser, J.I., and Nicol, G.W. 2011. Ammonia concentration determines

622 differential growth of ammonia-oxidising archaea and bacteria in soil microcosms. The

623 ISME Journal 5:1067-1071.

624 Vesterdal, L., et al. 2012. Soil respiration and rates of soil carbon turnover differ among six

625 common European tree species. Forest Ecology and Management 264:185-196.

626 Vesterdal, L., et al. 2013. Do tree species influence soil carbon stocks in temperate and boreal

627 forests? Forest Ecology and Management 309:4-18.

628 Vilgalys, R., Hester, M. 1990. Rapid genetic identification and mapping of enzymatically

629 amplified ribosomal DNA from several Cryptococcus species. Journal of Bacteriology.

$630 \quad 172: 4238-4246$.

631 Wallenstein, M.D., Myrold, D.D., Firestone, M., and Voytek, M. 2006. A synthesis of

632 denitrification. Ecological Applications. 16: 2143-2152.

633 Wardle, D.A. 1998. Controls of temporal variability of the soil microbial biomass: a global-scale

634 synthesis. Soil Biology and Biochemistry 30:1627-1637.

635 Wertz, S., Leigh, A.K.K., Grayston, S.J., 2012. Effects of long-term fertilization of forest soils

636 on potential nitrification and on the abundance and community structure of ammonia oxidizers and nitrite oxidizers. FEMS Microbiology Ecology 79, 142-154

638 White, T.J., et al. 1990. Amplification and direct sequencing of fungal ribosomal RNA genes for phylogenetics. In: Innis, M.A., Gelfand, D.H., Sninsky, J.J., White, T.J. (Eds.), PCR Protocols - a Guide to Methods and Applications. Academic Press, San Diego, CA, pp.

642 Wickham, H. 2009. ggplot2: elegant graphics for data analysis. Springer New York, USA. Book. 643

644

645 


\section{Figure legends}

647 Figure 1. Microbial biomass C, $\mathrm{N}$ and $\mathrm{C}: \mathrm{N}$ ratio in forest floors of four tree species at the two 648 sites (blue bars=Fairy Lake; green bars=San Juan; DF=Douglas-fir; SS=Sitka spruce; WH=western 649 hemlock; WRC=western red cedar).

Figure 2. Mean ( $\pm \mathrm{SE}$ ) gene abundance (log of gene copies/g soil) of total ammonia oxidizers (AOA amoA and AOB amoA) and total denitrifiers (nirK and nirS, bacteria (16S), and fungi (ITS) in the forest floors of four tree species at the two sites. Blue bars=Fairy Lake; green 654 bars=San Juan; DF=Douglas-fir; SS=Sitka spruce; WH=western hemlock; WRC=western red 655 cedar.

Figure 3. Rates of nitrogen transformations in the forest floors of four tree species at the two sites; (mean $\pm \mathrm{SE}$ ). Blue bars=Fairy Lake; green bars=San Juan; DF=Douglas-fir; $\mathrm{SS}=$ Sitka spruce; WH=western hemlock; WRC=western red cedar.

662 Figure 4. Regression of the sum of denitrification (nirK and nirS) and ammonia-oxidation (AOA 663 and $\mathrm{AOB}$ amoA) gene abundance by site ( $\mathrm{p}>0.05, * ; \mathrm{p}>0.01, * *, \mathrm{p}>0.001, * * *)$. Sites are 664 differentiated in the coordinate plot by colour (blue=Fairy Lake; green=San Juan) and tree 665 species are differentiated by symbols (circle=hemlock; triangle=Douglas-fir; diamond=spruce; 666 square=cedar).

668 Figure 5. Canonical redundancy analysis (RDA) and variation partitioning to determine the 669 factors contributing to the abundance of functional gene abundance at Fairy Lake and San Juan 670 sites. RDA was used to ordinate gene abundance measurements for total bacteria (16S), AOA

671 (amoA), AOB (amoA) and nitrite reducers (nirK and nirS) against forest floor physico-chemical

672 factors ( $\mathrm{pH}$, total $\mathrm{C}$, total $\mathrm{N}$ and $\mathrm{C}: \mathrm{N}$ ratio). Sites are differentiated in the coordinate plot by

673 colour (orange, Fairy Lake; green, San Juan) and tree species are differentiated by symbols

674 (circle=hemlock; triangle=Douglas-fir; diamond=spruce; square=cedar).

676 Figure 6. Conceptual model of $\mathrm{N}$ cycling processes at the two study sites with differing $\mathrm{N}$ status 677 - Fairy Lake and San Juan. 
679 Table 1. Group-specific primers for qPCR gene quantification assays.

\begin{tabular}{|c|c|c|c|}
\hline Primer Target & Primer Name & Primer Sequence (5'-3') & Reference \\
\hline $\begin{array}{l}\text { All Bacteria } \\
(16 \mathrm{~S} \text { rRNA) }\end{array}$ & $\begin{array}{l}519 \mathrm{~F} \\
907 \mathrm{R}\end{array}$ & $\begin{array}{l}\text { CAG CMG CCG CGG TAA NWC } \\
\text { CCG TCA ATT CMT TTR AGTT }\end{array}$ & $\begin{array}{l}\text { Baker et al. (2003) } \\
\text { Muyzer et al. (1995) }\end{array}$ \\
\hline All Fungi (ITS) & $\begin{array}{l}\text { ITS-1F } \\
5.8 \mathrm{~s}\end{array}$ & $\begin{array}{l}\text { TCC GTA GGT GAA CCT GCG G } \\
\text { CGC TGC GTT CTT CAT CG }\end{array}$ & $\begin{array}{l}\text { Gardes and Bruns (1993) } \\
\text { Vilgalys and Hester (1990) }\end{array}$ \\
\hline $\mathrm{AOA}^{\mathrm{a}}(a m o A)$ & $\begin{array}{l}\text { amoA-23F } \\
\text { amoA- 616R }\end{array}$ & $\begin{array}{l}\text { ATG GTC TGG CTW AGA CG } \\
\text { GCC ATC CAT CTG TAT GTC CA }\end{array}$ & Francis et al. (2005) \\
\hline$A O B^{b}(a m o A)$ & $\begin{array}{l}a m o A-1 \mathrm{~F} \\
a m o A-2 \mathrm{R}\end{array}$ & $\begin{array}{l}\text { GGG GTT TCT ACT GGT GGT } \\
\text { CCC CTC KGS AAA GCC TTC TTC }\end{array}$ & Rotthauwe et al. (1997) \\
\hline $\begin{array}{l}\text { Cd-nitrite } \\
\text { reductase (nirS) }\end{array}$ & $\begin{array}{l}\operatorname{nir} S-1 \mathrm{~F} \\
\operatorname{nirS}-3 \mathrm{R}\end{array}$ & $\begin{array}{l}\text { CCT AYT GGC CGG CRC ART } \\
\text { GCC GCC GTC RTG VAG GAA }\end{array}$ & Braker et al. (1998) \\
\hline $\begin{array}{l}\mathrm{Cu} \text {-nitrite } \\
\text { reductase }(\text { nirK })\end{array}$ & $\begin{array}{l}\operatorname{nirK}-1 F \\
\operatorname{nirK}-1 R\end{array}$ & $\begin{array}{l}\text { GGG CAT GAA CGG CGC GCT CAT GGT G } \\
\text { CGG GTT GGC GAA CTT GCC GGT GGT C }\end{array}$ & Braker et al. (1998) \\
\hline
\end{tabular}


681 Table 2. Forest floor chemistry: $\mathrm{pH}$, total soil C $(\mathrm{mg} / \mathrm{g}), \mathrm{N}(\mathrm{mg} / \mathrm{g})$, and C: $\mathrm{N}$ ratios of the four tree 682 species at the two sites. Mean \pm SE.

\begin{tabular}{llllll} 
Site & Tree species & pH & Total $\mathbf{C}\left(\mathbf{m g ~ g}^{-1}\right)$ & Total $\mathbf{~}\left(\mathbf{m g ~ g}^{-1}\right)$ & C:N ratio \\
\hline & WRC & $4.01 \pm 0.18$ & $436 \pm 31$ & $110 \pm 0$ & $38.5 \pm 3.1$ \\
San & DF & $3.95 \pm 0.02$ & $466 \pm 9$ & $135 \pm 1$ & $34.6 \pm 0.9$ \\
Juan & WH & $3.98 \pm 0.21$ & $449 \pm 17$ & $114 \pm 1$ & $39.4 \pm 1.0$ \\
& SS & $4.63 \pm 0.45$ & $369 \pm 85$ & $112 \pm 26$ & $33.6 \pm 0.9$ \\
& & & & \\
& WRC & $4.31 \pm 0.30$ & $485 \pm 8$ & $11.0 \pm 0.1$ & $44.0 \pm 0.6$ \\
Fairy & DF & $4.05 \pm 0.01$ & $430 \pm 52$ & $11.1 \pm 1.1$ & $38.5 \pm 0.9$ \\
Lake & WH & $3.75 \pm 0.03$ & $498 \pm 4$ & $10.5 \pm 0.2$ & $47.2 \pm 0.7$ \\
& SS & $4.29 \pm 0.05$ & $460 \pm 18$ & $11.8 \pm 0.5$ & $39.2 \pm 3.1$ \\
\hline
\end{tabular}

683 WRC=western red cedar; $\mathrm{DF}=$ Douglas-fir; $\mathrm{WH}=$ western hemlock; $\mathrm{SS}=$ Sitka spruce 
684 Table 3. F-statistics following permutation ANOVA testing of tree species (western red cedar, 685 Douglas-fir, western hemlock, Sitka spruce, $\mathrm{df}=3$ ), site (Fairy Lake, San Juan, df=1), and 686 interaction $(\mathrm{T} \times \mathrm{S}, \mathrm{df}=3$ ) effects on forest floor chemistry ( $\mathrm{pH}$, total $\mathrm{C}$, total $\mathrm{N}, \mathrm{C}: \mathrm{N}$ ratio), 687 microbial biomass $(\mathrm{C}, \mathrm{N}$ and $\mathrm{C}: \mathrm{N}$ ratios), $\mathrm{N}$ transformations (gross and net nitrogen 688 ammonification and nitrification, and $\mathrm{NH}_{4}{ }^{+}$and $\mathrm{NO}_{3}{ }^{-}$consumption) and microbial gene 689 abundances.

\begin{tabular}{lrrrrrr} 
Forest floor chemistry & Tree $(\mathrm{T})$ & \multicolumn{2}{c}{ Site $(\mathrm{S})$} & \multicolumn{3}{c}{ Tree x Site (T x S) } \\
& $F$ & $p$ & $F$ & $p$ & $F$ & $p$ \\
\hline $\mathrm{pH}$ & 2.93 & 0.10 & 0.08 & 0.79 & 0.90 & 0.48 \\
$\mathrm{C}$ & 0.89 & 0.49 & 2.03 & 0.20 & 0.97 & 0.43 \\
$\mathrm{~N}$ & 0.58 & 0.64 & 0.87 & 0.40 & 0.71 & 0.59 \\
$\mathrm{C}: \mathrm{N}$ & 8.49 & 0.01 & 23.77 & $<0.01$ & 0.45 & 0.71 \\
\hline Microbial biomass & & & & & & \\
MBC & 6.77 & 0.02 & 33.16 & $<0.01$ & 5.25 & 0.03 \\
MBN & 2.26 & 0.18 & 0.02 & 0.90 & 1.11 & 0.39 \\
MBC:N & 1.62 & 0.28 & 3.90 & 0.10 & 1.67 & 0.29 \\
\hline N transformation rates & & & & & & \\
Gross ammonification & 18.43 & $<0.01$ & 64.57 & $<0.01$ & 1.08 & 0.40 \\
Ammonium consumption & 6.75 & 0.01 & 7.31 & 0.03 & 0.50 & 0.73 \\
Net ammonification & 4.43 & 0.05 & 18.27 & 0.01 & 0.73 & 0.58 \\
Gross nitrification & 0.74 & 0.58 & 20.81 & $<0.01$ & 1.95 & 0.18 \\
Nitrate consumption & 1.19 & 0.38 & 132.72 & $<0.01$ & 1.68 & 0.25 \\
Net nitrification & 1.41 & 0.34 & 67.09 & $<0.01$ & 5.84 & 0.02 \\
\hline Microbial gene abundances & & & & & & \\
Bacteria 16S & 3.88 & 0.05 & 10.20 & 0.01 & 1.24 & 0.32 \\
Fungal ITS & 0.20 & 0.90 & 0.38 & 0.55 & 0.99 & 0.45 \\
AOA amoA & 0.76 & 0.51 & 18.62 & 0.01 & 0.02 & 1.00 \\
AOB amoA & 1.06 & 0.46 & 4.02 & 0.07 & 1.42 & 0.33 \\
nirK & 2.73 & 0.13 & 1.94 & 0.20 & 0.97 & 0.45 \\
nirS & 1.47 & 0.27 & 8.54 & 0.02 & 1.73 & 0.22 \\
\hline E & & & & &
\end{tabular}


Table 4. Multiple linear regressions of gross and net $\mathrm{N}$ ammonification and nitrification rates, 692 and consumption rates with adjusted $\mathrm{R}^{2}$ values, with best models selected using the lowest AIC 693 values.

694

\begin{tabular}{lccc}
\hline \multicolumn{4}{l}{ Gross ammonification = bacterial $16 S$ gene copies - fungal ITS gene copies } \\
Variable & Coefficient & t value & p-value \\
\hline bacteria $16 S$ gene copies & 1.057 & 6.253 & $2.96 \mathrm{E}-05$ \\
fungal ITS gene copies & -0.537 & -3.179 & 0.007 \\
\hline
\end{tabular}

F-statistics: 19.68 on 2 and 13 degrees of freedom; Adj. R2: 0.71; p-value: 0.0001168

\begin{tabular}{lccc}
\hline \multirow{2}{*}{$\begin{array}{l}\text { Gross NH4+ consumption = gross ammonification + C:N ratio + MBC:N ratio } \\
\text { Variable }\end{array}$ Coefficient } & t value & p-value \\
\hline Gross ammonification & 1.055 & 13.084 & $1.84 \mathrm{E}-08$ \\
Forest Floor C:N ratio & 0.243 & 2.68 & 0.020 \\
Microbial Biomass C:N ratio & 0.262 & 3.178 & 0.008 \\
\hline F-statistics: 61.5 on 3 and 12 degrees of freedom; Adj. R2: $0.92 ; \mathrm{p}$-value: $<0.001$ & \\
\hline
\end{tabular}

\begin{tabular}{lccc}
\hline $\begin{array}{l}\text { Net ammonification }=-\mathrm{C}: \mathrm{N} \text { ratio }-\mathrm{MBC}: \mathrm{N} \text { ratio } \\
\text { Variable }\end{array}$ & Coefficient & t value & p-value \\
\hline C:N ratio & -0.526 & 0.1538 & 0.005 \\
Microbial biomass C:N ratio & -0.486 & 0.1538 & 0.008 \\
\hline
\end{tabular}

F-statistics: 21.73 on 2 and 13 degrees of freedom; Adj. R2: 0.73; p-value: $<0.001$

\begin{tabular}{|c|c|c|c|}
\hline Variable & Coefficient & t value & p-value \\
\hline Microbial biomass $\mathrm{C}: \mathrm{N}$ ratio & 0.3401 & 1.77 & 0.100 \\
\hline amoA AOA gene copies & -0.5998 & -3.179 & 0.008 \\
\hline
\end{tabular}

F-statistics: 7.265 on 2 and 13 degrees of freedom; Adj. R2: 0.46; p-value: 0.008

\begin{tabular}{lccc}
\hline $\begin{array}{l}\text { Gross NO3- consumption }=\text { gross nitrification } \\
\text { Variable }\end{array}$ & Coefficient & t value & p-value \\
\hline gross nitrification & 0.7552 & 0.1752 & $<0.001$ \\
\hline
\end{tabular}

F-statistics: 18.58 on 1 and 14 degrees of freedom; Adj. R2: 0.54; p-value: <0.001

Net nitrification $=$ amoA $\mathrm{AOB}$ gene copies

\begin{tabular}{lccc} 
Variable & Coefficient & t value & p-value \\
\hline amoA AOB gene copies & 0.4775 & 2.034 & 0.061 \\
\hline
\end{tabular}

F-statistics: 4.135 on 1 and 14 degrees of freedom; Adj. R2: 0.1729; p-value: 0.061

696 Ammonification rates: $\mathrm{mg} \mathrm{N} \mathrm{kg}^{-1}$ soil $(\mathrm{dw}) \mathrm{d}^{-1}$; nitrification rates: $\mathrm{mg} \mathrm{N} \mathrm{g}^{-1}$ soil $(\mathrm{dw}) \mathrm{d}^{-1}$; microbial C and N, $\mathrm{mg} \mathrm{N} \mathrm{g}^{-1}$ soil (dw);

697 Bacterial 16S, Fungal ITS, AOA and AOB amoA: genes $\mathrm{g}^{-1}$ soil (dw). 